УдК 616.27

$\mathrm{DOI}$

(С) Т. В. МУРАВЙОВ, В. В. АРТЮХ, А. В. ДРОЗД

Житомирська обласна клінічна лікарня імені О. Ф. Гербачевського

\title{
Десятирічний досвід лікування хворих на гострий медіастиніт
}

\author{
T. V. MURAVYOV, V. V. ARTIUKH, A. V. DROZD \\ Zhytomyr Regional Clinical Hospital by O. F. Herbachevsky
}

\section{0-YEAR EXPERIENCE OF TREATMENT OF PATIENTS WITH AN ACUTE MEDIASTINITIS}

\begin{abstract}
Проблема діагностики та лікування гострого медіастиніту зберігає свою актуальність в зв’язку з тяжкістю захворювання та незадовільними результатами лікування. У статті представлено 10-річний досвід лікування 73 хворих на гострий медіастиніт різної етіології. Серед найбільш частих причин гострого медіастиніту є гнійно-запальні процеси щелепнолицевої зони та гнійна патологія ЛОР-органів у 56 (75,2 \%) хворих, які призводять до флегмони шиї та медіастиніту. На другому місці - 7 (10,2 \%) випадків перфорації стравоходу. Задовільний результат отримано в 64 (88,6 $7 \%)$ пацієнтів. Померли 9 хворих 12,33 \%. Основними причинами смерті стали гостра серцево-судинна недостатність та системна полі органна недостатність.

The problem of diagnosis and treatment of acute mediastenìtis retains its relevance due to the severity of the disease and the unsatisfactory results of treatment. The article presented a 10-year experience of treatment of 73 patients with an acute mediastenìt of different etiology. Among the most frequent causes of acute mediastenitis is a purulent-inflammatory processes of maxillofacial area and purulent pathology of ENT organs in 56 (65.2 \%) cases that lead to phlegmon of the neck and medìastenìt. At the second place - perforation of the esophagus $(10.2 \%)$. The positive result obtained in 64 cases (88.67\%). 9 patients died $(12.33 \%)$. The main causes of death was acute cardio-vascular insufficiency and system multiple organ failure.
\end{abstract}

Постановка проблеми і аналіз останніх досліджень та публікацій. Гострий медіастиніт - гостре гнійне запалення клітковини межистіння, що виникає в результаті ускладнення різноманітних захворювань. Гнійне запалення клітковини межистіння пребігає, як правило, у вигляді флегмони. Цьому сприяють анатомічні та фізіологічні особливості межистіння (рихла жирова клітковина, відсутність фасціальних бар'єрів, постійні дихальні рухи, пульсація серця та центральних судин). Висока всмоктувальна здатність приводить до швидкої вираженої інтоксикації та летального виходу протягом 1-5 діб від початку захворювання. Летальність при гострому медіастиніті, за даними різних авторів, сягає від 7,2 до $70 \%$.

За походженням виділяють первинний та вторинний медіастиніт.

Первинний (травматичний) медіастиніт виникає внаслідок:

1. Поранення межистіння з інфікуванням клітковини без або з ушкодженням його органів.

2. Інфікування клітковини межистіння при ушкодженні порожнистих органів межистіння (стравохід, трахея).

Вторинний:

1. Контактне розповсюдження інфекції з сусідніх органів та тканин (м'які тканини шиї, легені, перикард, черевна порожнина, заочеревинний простір)
2. Метастатичне розповсюдження інфекції при сепсисі.

За локалізацією виділяють:

1. Передній.

2. Задній.

3. Верхній.

4. Нижній.

5. Тотальний.

Мета роботи: покращити результати лікування хворих із гострим медіастинітом різної етіології.

Матеріали і методи. За 10 років у відділенні ЖОКЛ лікувалось 73 хворих на гострий медіастиніт. 3 них чоловіків було 39 (52 \%), жінок - 34 (48 \%). Вік пацієнтів: $18-40$ років - 26 (35,6 \%), 41-60 років - 30 (41,6 \%), 61 та старші $-17(23,3 \%)$.

Iз 73 пацієнтів у 38 (52,3 \%) осіб мала місце гнійна патологія щелепно-лицевої зони, у 18 (24,9 \%) хворих - патологія ЛОР-органів, у 7 (10,2 \%) перфорації стравоходу (табл. 1).

При госпіталізації всім пацієнтам проведено загальноклінічне обстеження: фізикальний огляд, загальний аналіз крові, загальний аналіз сечі, біохімічний аналіз крові, коагулограма, визначено групу крові, Rh. Рентгенографію органів грудної клітки виконували всім пацієнтам. При необхідності ви- 
Таблиця 1. Розподіл захворюваності на медіастиніт за етіологією

\begin{tabular}{||l|c|c|c||}
\hline \multicolumn{1}{|c|}{ Причини виникнення } & $\begin{array}{c}\text { Кількість } \\
\text { пацієнтів }\end{array}$ & $\begin{array}{c}\text { Кількість летальних } \\
\text { випадків }\end{array}$ \\
\hline Одонтогенний & 37 & 50,7 & 4 \\
\hline Заглотковий абсцес & 7 & 9,6 & 1 \\
\hline Паратонзилярний абсцес & 9 & 12,4 & 1 \\
\hline Остеомієліт шийного відділу хребта & 3 & 4,1 & \\
\hline Перфорація верхньої третини стравоходу (інструментальна) & 3 & 4,1 & \\
\hline Аденофлегмона & 3 & 4,1 & \\
\hline Відкритий травматичний перелом нижньої щелепи & 2 & 2,7 & \\
\hline Інфільтративно-флегмонозний ларингіт & 2 & 2,7 & \\
\hline Стороннє тіло стравоходу з перфорацією & 2 & 2,7 & 1 \\
\hline Спонтанний розрив стравоходу & 2 & 2,7 & \\
\hline Хронічний остеомієліт нижньої щелепи & 1 & 1,4 & \\
\hline Гострий гнійний тиреоїдит & 1 & 1,4 & \\
\hline Стороннє тіло шиї (скло) & 1 & 1,4 & \\
\hline \hline
\end{tabular}

конували комп’ютерну томографію шиї, грудної клітки. При підозрі на розрив стравоходу виконували рентгеноскопію стравоходу з водорозчинним контрастом, ЕФГДС.

Після дообстеження виявлено передній медіастиніт у 38 (52 \%) хворих, задній у 17 (23,4 \%) пацієнтів, передній та задній - у 12 (16,4 \%) осіб, нижній у 2 (2,7 \%) хворих, тотальний передній - у 4 (5,5 \%) пацієнтів (табл. 2).
При дообстеженні у хворих виявлено таку супутню патологію: IXC, стенокардію напруги, різноманітні аритмії - у 26 хворих, цукровий діабет - у 10 пацієнтів, гіпертонічну хворобу - у 8 осіб, ожиріння - у 6 хворих, хронічний гепатит у стадії загострення - у 3 пацієнтів, дисциркуляторну енцефалопатію та хворобу Бехтерева - по 2 випадки, алкогольний делірій, ревматичну хворобу серця зі стенозом гирла аорти, ХОЗЛ, туберкульоз легень - по 1 випадку.

Таблиця 2. Розподіл захворюваності на медіастиніт за локалізацією

\begin{tabular}{||l|c|c|c||}
\hline \multicolumn{1}{|c|}{ Локалізація } & Кількість пацієнтів & $\%$ & Кількість летальних випадків \\
\hline Передній & 38 & 52 & 3 \\
\hline Нижній & 2 & 2,7 & 3 \\
\hline Передній та задній & 12 & 16,4 & 1 \\
\hline Задній & 17 & 23,4 & 2 \\
\hline Тотальний & 4 & 5,5 & \\
\hline \hline
\end{tabular}

Результати досліджень та їх обговорення. Хворих обстежують та лікують згідно з наказом ДОЗ Житомирської обласної адміністрації 294 від 06.03.15. При наявності у хворого медіастиніту до лікування залучаються всі суміжні спеціалісти: торакальний хірург, анестезіолог, щелепно-лицевий хірург, ЛОР, хірург, ендоскопіст (за потребою).

Всім хворим проведено обстеження відповідно до стандартів, інтенсивну інфузійну, дезінтоксикаційну та антибактеріальну терапію протягом 2 год, після чого виконано операційне втручання.

Інтубацію трахеї було проведено за допомогою ларингоскопа в 33 (42,8 \%) пацієнтів, за допомогою фібробронхоскопа під місцевою анестезією у 31 (40,2 \%) хворого, при трахеотомії у 13 (17,0 \%) осіб. При гнійно-запальних процесах шиї з медіастинітом завжди виконували інтубацію трахеї під місцевою анестезією за допомогою фібробронхоскопа. При неможливості інтубації трахеї за допомогою ларингоскопа або фібробронхоскопа виконували трахеотомію в ургентному порядку.

Хворим було проведено від 1 до 4 операцій (табл. 3). При первинних операціях у 67 (91,8 \%) пацієнтів доступ до межистіння проведено через шийну медіастинотомію, в 2 (2,7 \%) хворих - через лапаротомний доступ, в 4 (5,5 \%) - шийну медіастинотомію + лапаротомію (при тотальному медіастиніті).

Повторні операції виконано в 42 хворих. Ревізію та редренування гнійних просторів - у 27 пацієнтів, дренування за Бюлау - в 10 осіб. Ушивання й перев'язку судин шиї та межистіння при арозивних кровотечах - у 3 хворих, гастростомію та торакотомію з медіастинотомією - по 2 пацієнти. 
Таблиця 3. Операції при медіастиніті

\begin{tabular}{|c|c|c|c|}
\hline Операції & $\begin{array}{l}\text { Кількість } \\
\text { пацієнтів }\end{array}$ & $\%$ & $\begin{array}{c}\text { Кількість летальних } \\
\text { випадків }\end{array}$ \\
\hline $\begin{array}{l}\text { Розкриття флегмони шиї, дренування переднього } \\
\text { середостіння, в тому числі з розкриттям флегмони дна } \\
\text { порожнини рота }\end{array}$ & $\begin{array}{l}35 \\
(5)\end{array}$ & 47,9 & $\begin{array}{l}3 \\
1\end{array}$ \\
\hline $\begin{array}{l}\text { Розкриття навкологлоткового абсцесу, флегмони шиї, } \\
\text { дренування переднього та заднього середостіння }\end{array}$ & 5 & 6,8 & 1 \\
\hline $\begin{array}{l}\text { Розкриття та дренування флегмони шиї, заднього } \\
\text { середостіння, в тому числі некрсеквестректомія С5 }\end{array}$ & $\begin{array}{c}9 \\
(2)\end{array}$ & 12,5 & $\begin{array}{l}2 \\
1\end{array}$ \\
\hline $\begin{array}{l}\text { Шийна медіастинотомія, ушивання стравоходу, дрену- } \\
\text { вання заднього середостіння }\end{array}$ & 3 & 4,1 & \\
\hline $\begin{array}{l}\text { Шийна медіастинотомія, дренування переднього та } \\
\text { заднього середостіння }\end{array}$ & 14 & 19,2 & 1 \\
\hline $\begin{array}{l}\text { Розкриття гнійного тиреоїдиту, флегмони шиї, дрену- } \\
\text { вання переднього середостіння }\end{array}$ & 1 & 1,3 & 1 \\
\hline $\begin{array}{l}\text { Розкриття та дренування флегмони шиї, наскрізне дре- } \\
\text { нування середостіння }\end{array}$ & 4 & 5,5 & \\
\hline $\begin{array}{l}\text { Лапаротомія, діафрагмотомія, ушивання стравоходу, } \\
\text { дренування нижнього середостіння }\end{array}$ & 2 & 2,7 & 1 \\
\hline
\end{tabular}

Примітка. Одинадцять пацієнтів були оперовані вперше з приводу флегмони шиї в інших лікувальних закладах.

Під час лікування у хворих виявлено такі ускладнення: двобічну полісегментарну пневмонію - у 21 (28,8 \%) хворий, плеврит - 11 (15 \%) пацієнтів, системну поліорганну недостатність - 7 (9,5 \%) осіб, арозивну кровотечу із судин шиї - 5
(6,9 \%) хворих, сепсис - 4 (5,5 \%) особи, перикардит - 3 (4,1 \%) пацієнти, міокардіодистрофію інтоксикаційного генезу - 3 (4,1 \%) хворих.

Тривалість перебування пацієнтів у стаціонарі та кількість летальних випадків показано у таблиці 4.

Таблиця 4. Тривалість перебування в стаціонарі

\begin{tabular}{||c|c|c|c||}
\hline \hline Ліжко-дні & Кількість пацієнтів & $\%$ & Кількість летальних випадків \\
\hline До доби & 1 & 1,4 & 1 \\
\hline $1-5$ & 2 & 2,7 & 2 \\
\hline $6-21$ & 44 & 60,3 & 4 \\
\hline Більше 22 & 26 & 35,6 & 2 \\
\hline
\end{tabular}

Із 73 хворих, які перебували на лікуванні, померли 9 осіб. Летальність склала 12,33 \%. Основними причинами смерті стали: двобічна полісегментарна пневмонія у 8 пацієнтів, системна поліорганна недостатність у 6 хворих, гостра серцево-судинна недостатність у 3 пацієнтів, набряк головного мозку в 2 осіб. Сепсис у 2 хворих, повторний гострий інфаркт міокарда - 1 пацієнт, арозивна кровотеча 3 судин шиї - 1 хворий. У більшості випадків причина смерті була мультифокальною.

Висновки. 1. Найбільш частою причиною медіастиніту $є$ гнійно-запальні процеси щелепнолицевої зони та гнійна патологія ЛОР-органів у 56 (65,2 \%) хворих, що призводять до флегмони шиї та медіастиніту. На другому місці - 7 (10,2 \%) випадків перфорації стравоходу.
2. При гнійно-запальному процесі в межистінні віддають перевагу активній хірургічній тактиці з інтенсивною інфузійною, антибактеріальною та дезінтоксикаційною терапією. Найбільш часто використовуються позаплевральні доступи 3 активним дренуванням межистіння.

3. При вищевказаній тактиці лікування в 64 (88,67 \%) пацієнтів отримано задовільний результат. У лікарні перебували 6-21 добу 44 (60,3 \%) пацієнти, померли 4 хворих. Ліжко-день становив більше 22 діб у 26 (35,6 \%) хворих, померли 2 пацієнти. Перебування хворих у стаціонарі до доби - 1 (1,4 \%) випадок, помер 1 хворий, ліжко-день 1-5 діб - 2 (2,7 \%) хворих, померли 2 пацієнти. Основними причинами летальності стали гостра серцевосудинна недостатність та системна поліорганна недостатність. 


\section{З ДОСВІДУ РОБОТИ}

\section{СПИСОК ЛІТЕРАТУРИ}

1. Мельников В. А. Флегмони шиї, ускладнені медіастинітом як наслідок інструментальних маніпуляцій / В. А. Мельников // Практична медицина. - 2002. - Т. 8, № 2. - С. 110113.

2. Соколов В. В. Застосування шийної медіастиноскопії при задньому верхньому перфоративному медіастиніті у хворої 93 років / В. В. Соколов, В. Г. Гетьман : матеріали наук.практ. конф. “Актуальні проблеми клінічної хірургії”, 17-18 травня 2012 р., Київ. - К., 2012.

3. Абакумов М. М. Двадцатилетний опыт диагностики и лечения при различных формах гнойного медиастинита / М. М. Абакумов, А. Н. Погодина, Т. Г. Бар // Вестник хирургии имени И. И. Грекова. - 2001. - № 1. - С. 80-85.

4. Доброквашин С. В. Хирургическое лечение больных с медиастинитом / С. В. Доброквашин, П. Н. Сысоев, С. Л. Демьянов // Практическая медицина. - 2014. - № 5 (81). - С. 47-49.

Отримано 08.07.15 